\title{
Щодо властивостей упаковки для захоронення сольового плаву АЕС України з реакторами ВВЕР у приповерхневих сховищах
}

- Ольховик Юрій Олександрович, д-р техн. наук

Державна установа «Інститут геохімії навколишнього середовища Національної академії наук України», м. Київ, Україна

ORCID: https://orcid.org/0000-0001-5653-2370

- Федоренко Юрій Григорович

Державна установа «Інститут геохімії навколишнього середовища Національної академії наук України», м. Київ, Україна

ORCID: https://orcid.org/0000-0001-7746-2332

- Розко Алла Миколаївна, канд. геол. наук, старш. наук. співроб. Інститут геохімії, мінералогії та рудоутворення ім. М. П. Семененка Національної академії наук України, м. Київ, Україна ORCID: https://orcid.org/0000-0002-4614-5569

- Рудичев Єгор Володимирович, канд. фіз.-мат. наук, старш. наук. співроб. Інститут фізики високих енергій і ядерної фізики Національний науковий центр «Харківський фізико-технічний інститут» Національної академії наук України, Харків, Україна Харківський національний університет ім. В. Н. Каразіна, м. Харків, Україна ORCID: https://orcid.org/0000-0002-1453-2062

Розглянуто поточну ситуацію зі зберіганням у сховищах АEC напрацьованого з 1987 року сольового плаву. Зазначено, що Запорізька АЕС впритул наблизилась до проблеми дефіциту вільних об'ємів для тимчасового зберігання контейнерів із сольовим плавом.

Детально розглянуто властивості гіпотетичної упаковки, прийнятної для захоронення сольового плаву без його переробки в разі віднесення сольового плаву до твердих радіоактивних відходів. Зазначено, що основним захисним бар'єром під час захоронення упаковки із сольовим плавом у приповерхневому сховищі слугуватиме геополімерна матриця, яка може розглядатися як перспективне середовище для іммобілізації кубового залишку або відпрацьованих фільтруючих матеріалів. Наведено результати експериментів щодо стійкості шлаколужних компаундів до вилуговування та радіаційного опромінення. Розраховані значення потужності дози на поверхні упаковки не перевищують 0,2 м3в/год. Показано, що незважаючи на високий вміст нітратів в упаковці, навіть у разі одночасної деструкції всіх контейнерів, розповсюдження шару води у водоносному горизонті з концентрацією нітрат-іону більш як 50 мг/дм ${ }^{3}$ не перевищить 100 - 150 метрів від зовнішньої межі сховища.

Зроблено висновок, що застосування ізолюючого геополімерного бар'єра $\epsilon$ основною умовою формування упаковки для безпечного і екологічно прийнятного захоронення сольового плаву в приповерхневих сховищах.

Ключові слова: геополімерна матриця, іммобілізація, контейнер, приповерхневе сховище, сольовий плав.

๑ Ольховик Ю. О., Федоренко Ю. Г., Розко А. М., Рудичев $\in$ В. В., 2021 
Проєктування AEC у колишньому СРСР базувалось на максимальному спрощенні системи поводження $з$ радіоактивними відходами (РАВ) і розв'язання питання їх майбутнього захоронення відкладалось на період зняття з експлуатації ядерних установок.

У сховищах АЕС України на поточний час накопичено велику кількість твердих і рідких відходів. Особливі складнощі виникають під час зберігання рідких РАВ (РРВ), які накопичуються в сховищах AEC у вигляді кубового залишку із солевмістом від 200 до 600 г/л, або у вигляді сольового плаву (СП) з більшою концентрацією солей. 31987 року на AEC України впроваджена технологія глибокого упарювання із застосуванням установок типу УГУ-1-500. Переробка кубового залишку на установках глибокого упарювання (УГУ) призводить до утворення ще більш концентрованого продукту (так званий СП), який у процесі охолодження застигає до твердого стану. Цей процес досить ефективно зменшує об'єм РРВ - від 4 до 15 разів, але широке використання УГУ призвело до виникнення низки проблем щодо подальшого поводження з СП.

За період з 1987 року до 31.12.2019 року включно в сховищах АЕС України з реакторами BBEP накопичено 45050 залізних контейнерів із

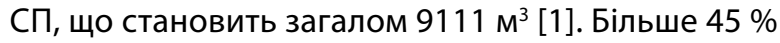
контейнерів, у яких на майданчиках Запорізької та Хмельницької АЕС зберігається СП, перевищили проєктний строк експлуатації.

Наразі загальнийоб'єм заповнення комірокдля зберігання СП з урахуванням об'єму контейнерів для Запорізької, Рівненської та Хмельницької АЕС становить 95,3, 63,5 і 70 \%, відповідно. Запорізька AEC упритул наблизилась до проблеми дефіциту вільних об'ємів для тимчасового зберігання контейнерів із СП. Переважна частина активності, накопиченої у сховищах на майданчиках діючих AEC, пов'язана саме із СП і становить приблизно $68 \%$ або ж $2,8 \cdot 10^{14}$ Бк [2].

Нагальною потребою галузевого рівня залишається реалізація заходів щодо подальшого поводження із СП, оскільки в Україні існує невизначеність щодо класифікації СП АЕС. Відповідно до п. 15.3 ОСПУ-2005 [3] до РРВ належать розчини неорганічних речовин, пульпи фільтрувальнихматеріалів, шлами, органічні рідини і СП без уточнення їх походження. Незважаючи на думку регулятора, що «Сольові плави, які отримуються внаслідок використання технології глибокого випарювання кубового залишку на AEC з реакторами ВBEР, мають бути віднесені до категорії твердих радіоактивних відходів» [4], [5] на сьогодні питання віднесення СП до категорії твердих РАВ (ТРВ) залишається невирішеним.

Віднесення СП до ТРВ дозволить впроваджувати необхідні заходи з його передачі до спецпідприємств на захоронення.
Накопичені наукові доробки щодо кондиціювання рідких боратвмісних РАВ дають підставу стверджувати про можливість формування безпечної упаковки для захоронення СП за умови внесення змін до ОСПУ-2005 [3] у разі віднесення СП до ТРВ.

Розглянемо більш детально гіпотетичну упаковку, запропоновану в [6]. СП складається, переважно, з гідратів розчинних солей - нітратів і боратів натрію і гідроксиду натрію, тому не може розглядатися як матричний матеріал для утримання радіонуклідів. Основні властивості продукту (СП) [7]:

вибухо- та пожежобезпечний, містить значні надлишки гідратної лужності, тому унеможливлює корозію вуглецевої сталі, яка контактує з сольовим продуктом;

розріджується за температури $120^{\circ} \mathrm{C}$, добре розчиняється у воді;

густина СП - 2-2,2 кг/дм³, вологість 70 - 120 г/кг; середній хімічний склад СП $\mathrm{AEC} з$ реакторами типу BBEP: $\mathrm{H}_{3} \mathrm{BO}_{3}-310,0$ г/кг; $\mathrm{Na}^{+}-180,0-223,0$ г/кг; $\mathrm{Cl}^{-}-5,0$ г/кг; $\mathrm{Fe}^{2+}-0,014-0,025$ г/кг; $\mathrm{SO}_{4}{ }^{2-}-29-95$ г/кг; $\mathrm{NO}_{3}^{-}-18$ - $28 \%$ [8], ізотопний склад ${ }^{134} \mathrm{Cs},{ }^{137} \mathrm{Cs},{ }^{60} \mathrm{Co}$.

\section{Бочки-контейнери для зберігання СП}

200-літрові контейнери А 2201.00 виготовлені зі Сталі 3 товщиною 3,5 мм. Для таких моделей контейнерів-бочок ЗП 551.040.00.000 та КРО-200 як основний матеріал використана Сталь 20 товщиною 3,9 мм. Усі вищезазначені контейнери мають обмежений строк експлуатації, який складає: для A2201.00.00, 3П 551.040.00.000 та КРО 200 відповідно 15, 10 і 20 років. 3 огляду на перебування сталі в лужному середовищі внутрішня корозія контейнерів відсутня, водночас на зовнішній поверхні спостерігаються корозійні процеси зі швидкістю 0,04 мм/рік [9], [10]. Оскільки критична для експлуатації контейнера товщина стінки складає 2,0 мм, цей контейнер не може розглядатися як довговічний інженерний бар'єр в контексті забезпечення довготривалої безпеки зберігання i захоронення СП.

\section{Захисний контейнер}

Для універсального залізобетонного контейнера УЗ3К (ТУ У 29.2-26444970-005 [11]), призначеного для транспортування та захоронення низько- і середньоактивних РАВ у поверхневих і приповерхневих сховищах, задекларована спроможність зберігати ізолюючі властивості протягом 300 років в умовах впливу факторів навколишнього середовища, що спричиняє обґрунтований сумнів. 
Людство не має досвіду експлуатації виробів із залізобетону протягом зазначеного періоду, адже патенти на портландцемент і залізобетон датовані лише 1824 і 1867 роком, відповідно. Найбільшою довговічністю 3 усіх видів будівельних виробів із мінеральних речовин характеризуються вироби з природних кам'яних матеріалів, про що свідчать тисячолітні пам'ятники будівельного мистецтва, що збереглися до наших днів.

Як усі техногенні вироби з часом контейнер деградує. Зауважимо, що деградація захисних характеристик контейнера багато в чому визнача$\epsilon$ ться комбінованим впливом чинників навколишнього середовища, людським фактором (якість виготовлення, експлуатаційне обслуговування) та факторами, зумовленими радіаційним випромінюванням розміщених у контейнері РАВ.

Одним 3 відомих механізмів руйнування бетону $\epsilon$ вилуговування - розчинення і вимивання компонентів бетону водою, зокрема гідроксиду кальцію $\mathrm{Ca}(\mathrm{OH})_{2}$, що $\epsilon$ найбільш розчинним компонентом цементного каменю. Деградація цементних матеріалів системи інженерних бар'єрів сховища визначається насамперед інтенсивністю і об'ємом інфільтрату. Інфільтрат, проходячи ґрунтове покриття, насичується природними розчин- ними компонентами і спричиняє зміни хімічного і мінерального складу бетону, що з часом призводить до деградації його ізолюючих властивостей. Еволюція складу порової води бетону і твердої фази під час вилуговування різними типами води була досліджена для контейнерів сховища Dessel, Бельгія [12]. Результати експериментів наведені на Рисунку 1 у вигляді кількості води (кг), необхідної для повного протікання відповідних стадій деградації 1000 см³ бетону, що вміщує $15 \%$ цементу.

Автори [12] довели, що кількість інфільтрату, необхідного для протікання відповідних стадій хімічної деградації бетону, в середньому складає 0,35, 70,4 і 1460 кг на 1000 см³ бетону для стадій I, II, i III, відповідно. 3 огляду на реальні значення інфільтраційного потоку в районі майданчиків «Вектор» і «Чистогалівка», що складає 200л/м².рік [13], можна було б очікувати, що бетонні споруди простоять десятки тисяч років. Але цей висновок здається надто оптимістичним 3 огляду на неможливість проєктувати дані лабораторних короткострокових експериментів з невеликим монолітним зразком на природні довгострокові (десятки і сотні років) процеси деградації великих бетонних споруд, тим більше не враховуючи процеси фізичної деградації бетонних матеріалів (карбонатизація, біодеструкція, корозія арматури тощо).

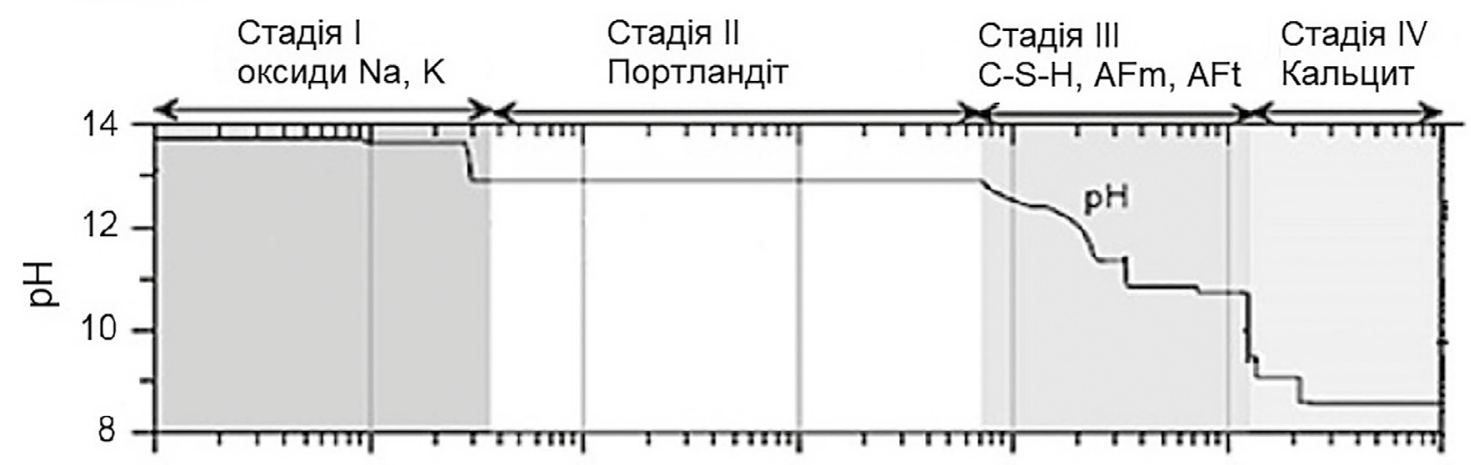

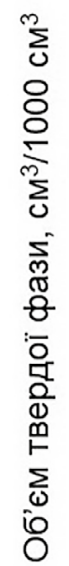

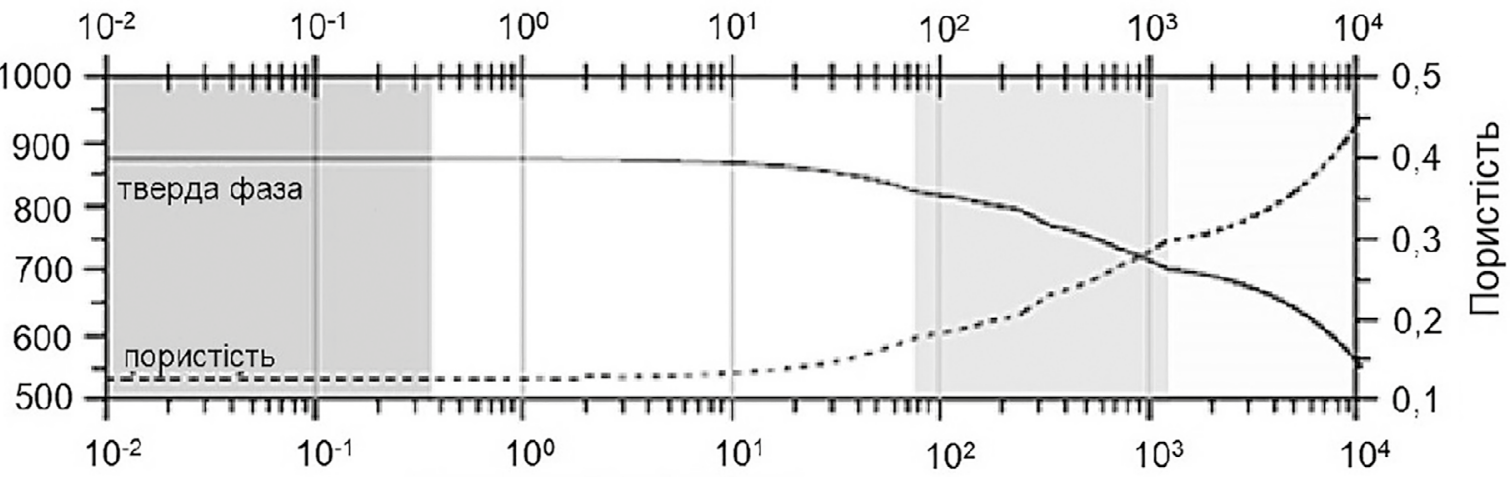

Рисунок 1 - Геохімічні зміни в цементі в процесі взаємодії з ґрунтовим інфільтратом 
Вироби з портландцементу в природних умовах приречені на руйнування, яке випливає 3 природи самого портландцементу і починається з першого моменту контакту цементного виробу з водою. Прикладом реального руйнування залізобетонних контейнерів із РАВ $є$ виявлені на Хмельницькій АЕС дефекти поверхонь залізобетонних контейнерів КX.T.PO-ІІ-5-20 типу «ББ-куб», розташованих на відкритому майданчику тимчасового зберігання. Кожний контейнер «ББ-куб» вміщує 12 бочок-контейнерів із СП і згідно із технічними умовами має строк придатності 300 років. Руйнування залізобетонних контейнерів призвело до необхідності перевантаження бочок із СП у стаціонарні сховища TPB, хоча експлуатація залізобетонних контейнерів «ББ-куб» розпочалась лише у 1990 році.

Упаковку у вигляді залізобетонного контейнера, в якому розміщено 4 залізні бочки-контейнери А2201, застосовано на Нововоронезькій АEC для довгострокового зберігання СП у легких поверхневих тимчасових ангарних сховищах на майданчику станції [14]. Втім зазначені заходи по суті $\epsilon$ відкладеним рішенням, яке перекладає тягар 3 вирішення проблеми поводження із СП на прийдешні покоління.

Отже, у разі захоронення СП виникає необхідність такої системи інженерних бар'єрів, яка спроможна гарантовано забезпечити ізоляцію радіонуклідів від довкілля як мінімум до моменту припинення адміністративного контролю, який для приповерхневих сховищ у Чорнобильській зоні відчуження відповідно до вимог НП 06.4.219-2018 [15] не повинен перевищувати 500 років. Заповнення пустот контейнера цементним каменем на основі портландцементу не може розглядатися як гарантовано ефективний засіб ізоляції з огляду на наведені раніше властивості зазначеного матеріалу. Якщо ж композицію на основі портландцементу використати для іммобілізації РPВ, то отримана у такий спосіб цементна матриця характеризується недостатньою для безпечного захоронення водостійкістю внаслідок негативного впливу значної кількості лугів, лужних солей (нітрати, борати), які входять до складу РРВ [16], [17]. Хоча безпека системизахоронення РАВ непокладається виключно на функціонування окремого бар'єра [15], але одночасне застосування захисного контейнера із портландцементу і насиченої солями цементної матриці на основі цього ж матеріалу в умовах довгострокового впливу факторів навколишнього середовища може призвести з часом до виникнення деструктивних процесів.

Це призводить до необхідності застосування в системі захоронення СП більш стійкого інженерного бар'єра, який наразі із високими експлуата- ційно-технічними характеристиками має відповідати сучасним вимогам щодо економічних і екологічних особливостей виробництва і застосування матеріалів і технологій. 3 огляду на визначені вимоги до додаткового бар'єра у складі упаковки для захоронення СП нині накопичено достатньо даних для впевненого використання 3 цією метою так званих «геополімерів». Геополімери - це різновид мінерального гідравлічного в'яжучого, який отримують за допомогою лужної активації алюмосилікатної сировини природного і техногенного походження. Геополімери являють собою альтернативні портландцементу в'яжучі, що спроможні забезпечити довгострокову безпеку захоронення середньоактивних відходів у приповерхневих сховищах з огляду на високу міцність і довгострокову стабільність штучного каменю, отриманого на їх основі.

Взаємодія природних алюмосилікатів зі сполуками лужноземельних і лужних металів призводить до утворення низькоосновних гідросилікатів кальцію, лужних і лужноземельних гідроалюмосилікатів, що $\epsilon$ аналогами природних породоутворюючих мінералів - цеолітів, чим пояснюється здатність цих цементів не тільки зберігати, але і підвищувати показники своїх властивостей під час тривалого зберігання [18]. Для цієї групи цементів використовують кілька назв - активовані лугами цементи, лужноактивовані в'яжучі, лужні цементи, лужні в'яжучі, геополімери.

Теоретичні і практичні результати досліджень у сфері спрямованого синтезу лужних і лужнолужноземельних алюмосилікатних в'яжучих систем [16], [17] дозволили науково обґрунтовано підійти до питання використання лужних цементів для ефективної і надійної локалізації рідких високосольових РАВ. Особливістю структуроутворення таких цементів $\epsilon$ синтез лужних i змішаних лужно-лужноземельних алюмосилікатів, які мають досить високу сорбційну здатність, що, разом із хімічним зв'язуванням радіонуклідів у складі синтезованих цеолітів структур, забезпечує фізичне блокування радіоактивних елементів і високе наповнення неорганічними солями [19]. Високі іммобілізуючі властивості лужних цементів підтверджені результатами досліджень вилуговування цезію i стронцію з використанням як модельних систем імітаторів рідких боратвмісних РРВ [20]-[22], так і через дослідне кондиціювання реальних РРВ українських станцій: Хмельницької АЕС (реактор типу BBEP) і Чорнобильської АEC (реактор типу РБМК) [19].

В експериментах із компаундами на основі шлаколужних цементів із добавкою цеолітів, у яких використовувався імітат бормісних PРВ із сольовим вмістом 750 г/дм³, доведено, 
що швидкість вилуговування стабільного Cs

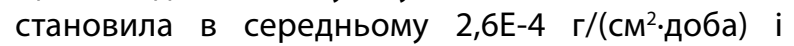
досягає значення нормативного показника $1 \mathrm{E}-3$ г/(см².доба) [23] на 85 добу від початку експерименту за соленаповнення $24 \%$. Зразки після ү-опромінення дозою 10 кГр і після 30 циклів заморожування зберігали високу міцність на стиск і відповідали регламентованим вимогам. Доведено можливість поліпшення певної характеристики компаунду через варіацію складу геополімеру [24].

Швидкість вилуговування радіонуклідів із компаундів на основі шлаколужних цементів із продуктів кондиціювання зразків реальних РРВ

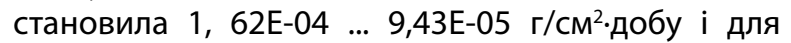
2,14E-04 - 8,83E-05 г/см².добу (реактори типу ВВЕР і РБМК, відповідно), тоді як у разі використання портландцементу ці показники на порядок вищі. Характеристики міцності компаундів також значно перевищують портландцементну систему і складають 11,4 - 18,8 МПа у разі наповнення компаундів солями 21 - 29 мас\% [19]. Висока міцність, низька пористість і лужний характер геополімерних компаундів забезпечують відсутність внутрішньої корозії металевих контейнерів і запобігають контакту атмосферної вологи із гігроскопічним СП.

Отже, базуючись на високих ізоляційних властивостях геополімерів, гіпотетична упаковка для спільного захоронення СП і кондиційованого кубового залишку може виглядати так:

1) зовнішняоболонка-універсальнийзалізобетонний контейнерУЗЗКТУУ 29.2-26444970-005 [11] із внутрішнім об'ємом 2,25 м³;

2) у внутрішньому об'ємі $2,25 \mathrm{~m}^{3}$ посередині розміщено 4 контейнери КРО-200 загальним

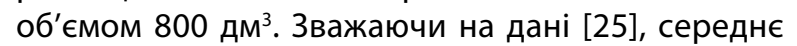
наповнення контейнера-бочки складає 162 дм³, отже, сумарний вміст СП становить приблизно 1300 кг за щільності 2,0 кг/дм;

3) залишок об'єму 1,45 м³ заповнений продуктом кондиціювання кубового залишку у вигляді лужного цементу із соленаповненням $25 \%$. Приймаючи щільність цементованих РАВ 2,2 т/м, розраховано, що в контейнері УЗЗК може розміститися 800 кг солей за загальної ваги компаунду 3200 кг;

4) загальна вага упаковки становитиме приблизно 12470 кг, що не перевищує масу брутто, зазначену в ТУ У 29.2-26444970-005 [11];

5) можливими різновидами складу упаковки $\epsilon:$ розміщення в упаковці виключно СП без іммобілізації кубового залишку в геополімерну матрицю у разі глибокого випарювання всього об'єму кубового залишку;

розміщення в упаковці СП із іммобілізацією у геополімерну матрицю відпрацьованих фільтруючих матеріалів. Можливість такого процесу доведено в [26].

\section{Потужність дози на поверхні гіпотетичної упаковки}

Фактичні значення потужності експозиційної дози безпосередньо на поверхні бочокконтейнерів із СП за даними Хмельницької АЕС складають у середньому 5 мЗв/год [25]. Радіоактивні матеріали, що розміщуються в упаковці, належать до групи LSA-II згідно 3 Правилами безпечного перевезення радіоактивних матеріалів [27].

Оскільки вищезазначена упаковка має транспортуватися у сховище для захоронення, вона має відповідати таким умовам: потужність дози за звичайних умов перевезення не повинна перевищувати 2 мЗв/год у будь-якій точці зовнішньої поверхні транспортного засобу або вантажного контейнера і 0,1 мЗв/год на відстані 2 м від неї [27].

Моделювання потужності експозиційної дози здійснювалося за допомогою програмного комплексу PHITS (Японія) [28]. У моделі враховувались 4 металеві бочки зі сталі товщиною 3,9 мм, заповнені СП зі щільністю 2,0 кг/дм ${ }^{3}$ і розташовані в середині УЗ3К. Залишок внутрішнього простору було заповнено лужним цементом (Рисунок 2). Розглянуто 2 варіанти: перший заливка із соленаповненням $25 \%$ та другий варіант без соленаповнення. Товщину бетону і геометрію Уз3К було взято згідно 3 ТУ У 29.2-26444970-005 [11]. Схема розташування 4 циліндричних контейнерів об'ємом 200 л із позначенням відстані між ними всередині контейнера УзЗК зображено на Рисунку 2.

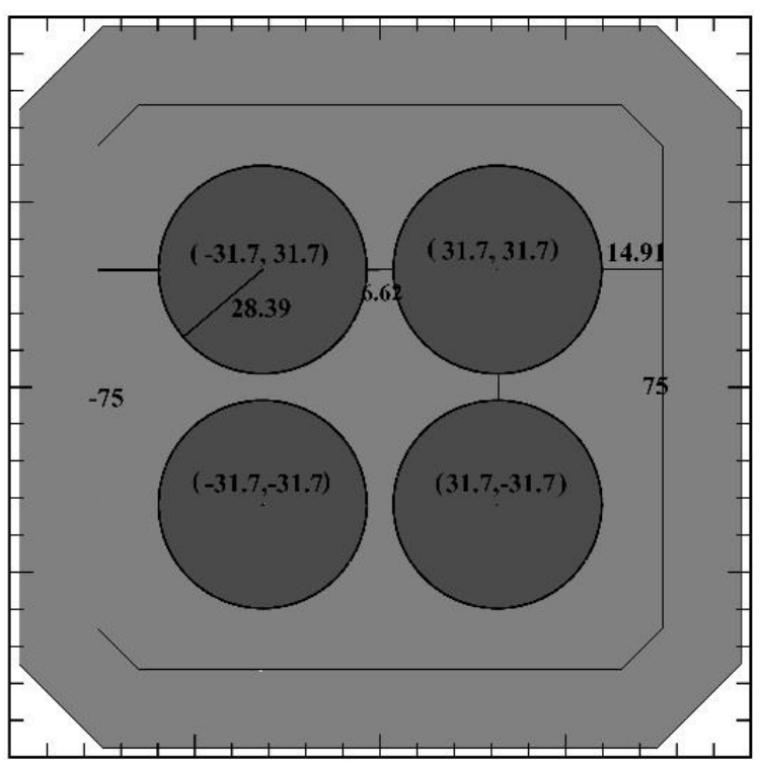

Рисунок 2 - Схема розташування 4 циліндричних контейнерів об'ємом 200 л 
Таблиця 1 - Розрахована потужність дози упаковки із СП, мкЗв/год (кришка/бокова стінка)

\begin{tabular}{|c|c|c|c|c|c|c|}
\hline \multirow{3}{*}{$\begin{array}{l}\text { Відстань, } \\
\text { см }\end{array}$} & \multicolumn{6}{|c|}{ Ізотопний склад СП } \\
\hline & \multicolumn{2}{|c|}{${ }^{137} \mathrm{Cs}-100 \%$} & \multicolumn{2}{|c|}{$\begin{array}{c}{ }^{137} \mathrm{Cs}-75,2 \%,{ }^{134} \mathrm{Cs}-24 \% \\
{ }^{60} \mathrm{Co}-0,8 \%[28]\end{array}$} & \multicolumn{2}{|c|}{$\begin{array}{c}{ }^{137} \mathrm{Cs}-65 \%,{ }^{134} \mathrm{Cs}-15 \% \\
{ }^{60} \mathrm{Co}-20 \%[12]\end{array}$} \\
\hline & $\begin{array}{l}\text { Соленапов- } \\
\text { нення } 25 \%\end{array}$ & $\begin{array}{c}\text { Соленапов- } \\
\text { нення } 0 \text { \% }\end{array}$ & $\begin{array}{l}\text { Соленапов- } \\
\text { нення } 25 \%\end{array}$ & $\begin{array}{c}\text { Соленапов- } \\
\text { нення } 0 \text { \% }\end{array}$ & $\begin{array}{l}\text { Соленапов- } \\
\text { нення } 25 \%\end{array}$ & $\begin{array}{c}\text { Соленапов- } \\
\text { нення } 0 \%\end{array}$ \\
\hline 30 & $34,14 / 22$ & $2,38 / 1,26$ & $71,93 / 43,8$ & $5,93 / 3,11$ & $142,6 / 96,05$ & $17,67 / 9,62$ \\
\hline 100 & $17,91 / 9,78$ & $1,2 / 0,68$ & $37,52 / 19,26$ & $2,88 / 1,64$ & $72,87 / 42,99$ & $8,27 / 4,85$ \\
\hline
\end{tabular}

Виконані розрахунки потужності експозиційної дози для СП з питомою активністю 5 Е7 Бк/кг (винятково ${ }^{137} \mathrm{Cs}$ ) і 6,7Е7 Бк/кг для суміші радіонуклідів ${ }^{137} \mathrm{Cs},{ }^{134} \mathrm{Cs},{ }^{60} \mathrm{Co}$. Наявність металевої арматури в складі УЗЗК консервативно не враховувалась. Результати розрахунку наведені в Таблиці 1.

Результати розрахунків свідчать, що запропонована гіпотетична упаковка забезпечує дотримання правил безпеки під час транспортування.

\section{Оцінка забруднення підземних вод неорганічними солями}

Для створення повної картини можливої поведінки упаковки із СП розглянемо маловірогідну ситуацію руйнування в далекому майбутньому геополімерного блока із надходженням розчинних солей у навколишнє середовище через корозію металевої оболонки. Єдиним шляхом міграції сольових розчинів, що утворяться у процесі взаємодії метеоопадів із складовими СП, є інфільтрація у верхній водоносний горизонт. Потужність Н водоносного горизонту складає в середньому 25 м, величина середньобагаторічного (за останні 60 років) інфільтраційного живлення підземних вод становить $\varepsilon=200 \mathrm{~mm} /$ рік $=200 \mathrm{л} /\left(\mathrm{M}^{2}\right.$.рік).

Для оцінки захисної здатності водоносного комплексу четвертинних відкладень розглянуто референтний сценарій потенційного надходження нітрат-іону з питною водою зі свердловини (чи колодязя), оскільки саме цей компонент СП $\epsilon$ критичним за санітарно-токсикологічним показником [29]. Оскільки сорбція аніону $\mathrm{NO}_{3}{ }^{-}$відсутня, розповсюдження нітрат-іону у водоносному горизонті буде визначатися швидкістю руху підземного потоку і гідродинамічною дисперсією. Реальні значення відповідних коефіцієнтів гідродисперсії для водовміщуючих пород у районі розташування сховища «Вектор» не визначено, відсутня кількісна оцінка інтенсивності перемішування верхніх шарів води і масштабу водообміну з нижнім еоценовим горизонтом внаслідок недосконалості в будові київського мергелю. Зазначені процеси призведуть до зменшення питомої концентрації нітратів у забрудненій воді, хоча наявні дані не дають змоги кількісно оцінити ступінь розбавлення.

За гігієнічним нормативом питома концентрація нітратів не може перевищувати 50 мг/дм ${ }^{3}$ для питної води із колодязів або свердловин [29]. Використаємо цю величину як граничну умову для оціночного розрахунку масштабів гіпотетичного забруднення підземних вод.

Вихідні дані: приймаємо, на сховищі ТРВ-1 комплексу «Вектор» розміщено 50000 контейнерів-бочок із СП, які упаковані в захисні залізобетонні контейнери УЗЗК у кількості 12500 одиниць. Зважаючи на проєктну потужність сховища ТРВ-1, що складає 4600 контейнерів, для розміщення зазначеної кількості СП необхідно використати 3 таких сховища, лінійні розміри кожного із яких складають приблизно 200×40 м. Тобто навіть у неймовірній ситуації одночасної деструкції всіх контейнерів джерело забруднення солями буде мати не точковий, а локальний масштаб. Вміст нітратіону в СП приймемо за 28 \% за даними [9], товщина верхнього шару інтенсивного перемішування водоносного горизонту оцінена в 5 м за пористості грунтів 0,35 [30].

3 огляду на наведені дані можна зазначити, що внаслідок інтенсивного розбавлення забрудненої води у водоносному горизонті розповсюдження шару води 3 концентрацією нітрат-іону більш як 50 мг/дм ${ }^{3}$ не перевищить 100 - 150 м від зовнішньої межі сховища.

\section{Висновки}

1) Сучасний рівень наукових доробок дає підстави для створення технології захоронення СП без його переробки. Застосування ізолюючого геополімерного бар'єра $\epsilon$ основною умовою формування упаковки для безпечного і екологічно прийнятного захоронення СП у приповерхневих сховищах. 
2) Упаковка у складі «залізобетонний контейнер - геополімерний блок - контейнер із СП» за величиною потужності дози відповідає умовам безпеки транспортування і розміщення в приповерхневому сховищі для захоронення. Потужність дози на поверхні упаковки не перевищить 2 мЗв/год.

3) Зарахування СП, накопиченого в сховищах AEC з реакторами ВBEP, до категорії ТРВ $\epsilon$ необхідною умовою для реалізації практичних заходів 3 іммобілізації РPВ АЕС України з наступною їх передачею на захоронення.

4) Іммобілізація кубового залишку в геополімерний камінь $\epsilon$ перспективним напрямком створення форми відходів, прийнятної для захоронення і здатної забезпечити довгострокову ізоляцію відходів від навколишнього середовища.

5) Актуальною задачею $\epsilon$ виконання технікоекономічного аналізу для визначення оптимального складу гіпотетичної безпечної упаковки, а саме: що $є$ більш доцільним - іммобілізація накопиченого кубового залишку в геополімер чи глибоке випарювання всього кубового залишку із наступним захороненням у вигляді СП.

6) Для підтвердження безпеки захоронення вищезазначених гіпотетичних упаковок, має бути розглянутий гіпотетичний сценарій поведінки упаковки із СП у довгостроковий період, пов'язаний із руйнуванням геополімерного блока, корозією металевих бочок та поширенням розчинних радіонуклідів у ґрунтові води.

\section{Список використаної літератури}

1. Інформація щодо поводження 3 радіоактивними відходами при експлуатації АЕС ДП «НАЕК «Енергоатом» (станом на 31.12.2019). URL: https://www.energoatom.com. ua/uploads/2020/\%D0\%98\%D0\%BB\%D0\%BB.\%20\%D0\%BE\% D1\%82\%D1\%87\%D0\%B5\%D1\%82_2019.pdf.

2. Лист ДП «НАЕК «Енергоатом» від 09.01.2018 № 9-КФ, конфіденційно.

3. ДСП 6.177-2005-09-02. Основні санітарні правила забезпечення радіаційної безпеки України. Затвердж. Наказом МО3 України від 02.02.2005 № 54, зареєстр. в Міністерстві юстиції України 20.05.2005 за № 552/10832. URL: https://zakon.rada.gov.ua/laws/show/z0552-05\#Text.

4. Лист МОЗ від 07.11.2007 № 7.04/58/2683.

5. Проект наказу Міністерства охорони здоров'я України «Про внесення змін до Основних санітарних правил забезпечення радіаційної безпеки України». URL: http://old.moz.gov.ua/ua/print/dn_20151214_0.html

6. Ольховик Ю.О. Перспективні схеми кондиціювання рідких радіоактивних відходів АЕС України. Ядерна енергетика та довкілля 2020. №3(18). С. 48-56. doi: 10.31717/2311-8253.20.3.6.

7. Обращение с радиоактивными отходами при эксплуатации АЭС НАЭК «Энергоатом» (по состоянию на 31.12.2005 г.)
8. Мальцева Т.В. Анализ возможности применения эффективных сорбционных материалов для переработки жидких отходов на АЭС Украины. Вода $і$ водоочисні технології. Науково-технічні вісті. 2015. № 2(17). С. 50 - 61.

9. Акт дослідження сольового плаву, стану металу та зварних з'єднань контейнерів 3П.551.040 від 20.12.1999, затверджений Головним інженером ВП «Хмельницька АЕС» В. І. Софіюком.

10. Акт про обстеження технічного стану контейнерів для радіоактивних відходів типу 3П551.040.00.00, А2201.00.000 від 29.08.2008, затверджений Головним інженером ВП «Запорізька АЕС» О. В. Шавлаковим

11. ТУ У 29.2-26444970-005:2013. Контейнер універсальний захисний залізобетонний Уз3К. Технічні умови. Погоджено Держатомрегулюванням України листом від 20.07.2015 № 19-11/4585.

12. Selection of near field parameters for the Dessel near surface repository. NIROND-TR-2010-07E. 2 December 2011.

13. Бугай Д.А., Фурре Д.А.Э., Жан-Баптист П., Дапоньи А., Бомьер Д., Галь К.Ле, Ланселот Ж., Скальский А. С., Ван Меер Н. Оценка водообмена подземных вод в ближней зоне ЧАЭС на основе данных изотопного датирования и гидрогеологического моделирования. Геологический журнал. 2010. № 4. С. 119 - 124.

14. Росновский С.В., Булка С.К. Методология кондиционирования отвержденных радиоактивных отходов с применением контейнеров Н3К с хранением в легких хранилищах ангарного типа. Сборник трудов 8-й международно-технической конференции «Обеспечение безопасности АЭС С ВВЭР» (28-31 мая 2013 г., ОАО ОКБ «ГИДРОПРЕСС»), ПодольСК, Россия. URL: http://www.gidropress.podolsk.ru/files/proceedings/ mntk2013/autorun/article136-ru.htm.

15. НП 306.4.219-2018. Загальні положення безпеки при захороненні радіоактивних відходів. Затвердж. наказом Держатомрегулювання від 13.08.2018 № 331 та зареєстр. в Міністерстві юстиції України 05.09.2018 за № 1008/32460.

16. Глуховский В.Д. Щелочные и щелочноземельные гидравлические вяжущие и бетоны. Киев: Вища школа. 1979. 232 c.

17. Кривенко П.В., Рунова Р. Ф., Саницкий М. А., Руденко И. И. Щелочные цементы. Киев: Основа, 2015. 446 с.

18. Рахимов Р.3., Рахимова Н.Р., Ожован М.И. Шлакощелочные вяжущие, растворы и бетоны для защиты от экологической и радиационной опасности. Bопросы радиационной безопасности. 2012. № 3. С.11- 17.

19. Кривенко П. В.,Петропавловський О. Н.,Гелевера А. Г., Вознюк Г. В. Утилизация и локализация токсичных отходов В шлакощелочных бетонах и компаундах. Будівельні матеріали, вироби та санітарна техніка. 2012. Вип. 43. C. 87 - 100. URL: http://nbuv.gov.ua/UJRN/bmvs_2012_43_17.

20. Розко А.М., Федоренко Ю.г. Особливості цементування борвміщуючого імітату рідких радіоактивних відходів шлаколужним з'вязуючим з цеолітом. Проблеми зняття 3 експлуатації об'єктів ядерної енергетики та відновлення навколишнього середовища (INUDECO 19): збірник матеріалів IV Міжнародної конференції (24-26 квітня 2019, м. Славутич). Чернігів: ЧНТУ. 2019. С. 216. 
21. Rozko A., Fedorenko Yu., Zadvernyuk H. Zeolite as component binding materials for liquide radioactive waste conditioning. Пошукова та екологічна геохімія. 2019. № 1(20). C. $29-31$.

22. Ольховик Ю.О., Федоренко Ю.Г., Розко А.М., Саєнко С. Ю., Шкуропатенко В. А. Цементування боратвмісних рідких радіоактивних відходів за підвищеної температури. Ядерна енергетика та довкілля. 2019. № 1(13). С. 59- 66.

23. ГОСТ Р 52126-2003. Отходы радиоактивные. Определение химической устойчивости отвержденных высокоактивных отходов методом длительного выщелачивания.

24. Розко А.М., Федоренко Ю.Г., Ольховик Ю.О., Павлишин Г. П. Межа міцності на стиск компаундів, отриманих при цементуванні високосольових борвміщуючих РPB геополімерними зв'язуючими. Геохімія техногенезу. 2020. № 4. C. 96 - 101. doi: 10.15407/geotech2020.32.096.

25. Жигалов Я.А., Пшеничний В.А. Визначення коефіцієнта ослаблення потужності еквівалентної дози гамма-випромінювання матеріалом оболонки циліндричних контейнерів для тимчасового зберігання рідких радіоактивних відходів. Ядерна та радіаційна безпека. 2014. № 1(61). С. 34 - 44.

26. Krivenko P., Cao H., Petropavlovskii O., Weng L., Kovalchuk O. Efficiency of Alkali Activated Hybrid Cements for Immobilization of Low-Level Radioactive Anion-Exchange Rezins. Eastern-European Journal of Enterprise Technologies. 2016. Vol. 5. No. 10(83). P. 38 - 42. doi: 10.15587/17294061.2016.59488.

27. Правила ядерної та радіаційної безпеки при перевезенні радіоактивних матеріалів (ПБПРМ-2006). Затвердж. наказом Держатомрегулювання України від 30.08.2006 №132, зареєстр. в Міністрестві юстиції Укаїни 18.09.2006 за № 1056/12930.

28. Iwase H., Niita K., Nakamura T. Development of generalpurpose particle and heavy ion transport Monte Carlo code. Journal of Nuclear Science and Technology. 2002. V. 39. No. 11. P. 1142 - 1151. doi: 10.1080/18811248.2002.9715305.

29. Державні санітарні норми та правила «Гігієнічні вимоги до води питної, призначеної для споживання людиною» (ДСанПіН 2.2.4-171-10). Затвердж. наказом Міністерства охорони здоров'я України 12.05.2010 № 400, зареєстр. в Міністерстві юстиції України 01.07.2010 за № 452/17747. URL: https://zakon.rada.gov.ua/laws/show/ z0452-10\#Text

30.Ольховик Ю.О. Щодо захисних властивостей зони аерації майданчика комплекса «Вектор». Ядерна енергетика та довкілля. 2015. № 2(6). С.65 - 59.

\section{References}

1. Information on radioactive waste management during operation of Energoatom NPPs (as of 31 December 2019). Retrieved from: https://www.energoatom.com.ua/ uploads/2020/\%D0\%98\%D0\%BB\%D0\%BB.\%20\%D0\%BE\% D1\%82\%D1\%87\%D0\%B5\% D1\% 82_2019.pdf.
2. Energoatom letter No. 9-CF dated 9 January 2018, confidential.

3. DSP 6.177-2005-09-02. Basic Sanitary Rules of Radiation Safety of Ukraine. Approved by Order of the Ministry of Health of Ukraine No. 54 of 2 February 2005. Retrieved from: https://zakon.rada.gov.ua/laws/show/z0552-05\#Text.

4. Letter of the Ministry of Health No. 7.04/58/2683 dated 7 November 2007.

5. Draft Order of the Ministry of Health of Ukraine "On Amendments to the Basic Sanitary Rules of Radiation Safety of Ukraine». Retrieved from: http://old.moz.gov.ua/en/ print/dn_20151214_0.html.

6. Olkhovyk, Yu. (2020). Perspective schemes of conditioning of liquid radioactive waste of Ukrainian NPPs. Nuclear Energy and Environment, 3 (18), 48 - 56. doi: 10.31717/2311-8253.20.3.6.

7. Radioactive waste management during operation of Energoatom NPPs (as of 31 December 2005).

8. Maltseva, T. (2015). Analysis of the possibility of using effective sorption materials for liquid waste processing at Ukrainian NPPs. Water and Water Treatment Technologies. Scientific and Technical News, 2 (17), 50 - 61.

9. Certificate of research of salt melt, state of metal and welded joints of containers ZP.551.040 dated 20 December 1999 approved by Chief Engineer of Khmelnitsky NPP V. Sofiiuk.

10. Certificate on inspection of technical condition of containers for radioactive waste, ZP551.040.00.00, A2201.00.000 dated 29 August 2008 approved by Chief Engineer of Zaporizhzhya NPP O. Shavlakov.

11. TU U 29.2-26444970-005:2013. Container universal protective reinforced concrete UZZK. Specifications. Approved by Letter of the SNRCU No 19-11/4585 of 20 July 2015.

12. Selection of near field parameters for the Dessel nearsurface repository. NIROND-TR-2010-07E. 2 December 2011.

13. Bugay, D., Fourier, D., Jean-Baptiste, P., Daponyi, A., Bomier, D. Le Gaul, K., Lancelot, J., Skalskyi, A., Van Meyer, N. (2010). Estimation of groundwater water exchange in the near zone of the Chornobyl nuclear power plant on the basis of isotope dating and hydrogeological modeling data. Geological Journal, 4, 119 - 124

14. Rosnovskyi, S., Bulka, S. Methodology for conditioning cured radioactive waste using NZK containers with storage in light hangar-type storage facilities. Collection of the documents of the 8th International Technical Conference «Safety of VVER NPPs», OKB «GIDROPRESS» JSC, 28 - 31 May 2013, Podolsk, Russia. Retrieved from: http://www.gidropress.podolsk.ru/files/ proceedings/mntk2013/autorun/article136-ru.htm.

15. NP 306.4.219-2018 General safety provisions for radioactive waste disposal. Approved by Order of the State Nuclear Regulatory Inspectorate of Ukraine No. 331 dated 13 August 2018 and registered in the Ministry of Justice of Ukraine under No. 1008/32460 on 5 September 2018.

16. Glukhovskyi, V. (1979). Alkaline and alkaline-earth hydraulic binders and concretes. Kyiv, Higher school, 232 p.

17. Krivenko, P., Runova, R., Sanitskyi, M., Rudenko, I. (2015). Alkaline cements. Kyiv, Osnova, 446 p. 
18. Rakhimov, R., Rakhimova, N., Ozhovan, M. (2012). Alkaline binders, mortars and concretes for protection against environmental and radiation hazards. Radiation safety issues, 3 , $11-17$.

19. Krivenko, P., Petropavlovsky, O., Gelevera, O., Voznyuk, G. (2012). Utilization and localization of toxic waste in slag-alkaline concretes and compounds. Building materials, products and sanitary ware. 43, 87 - 100. Retrieved from: http://nbuv.gov.ua/ UJRN/bmvs_2012_43_17.

20. Rozko, A., Fedorenko, Yu. (2019). The use of slagalkaline binders with zeolite for cementing boron-containing imitation LRW. Decommissioning issues of nuclear energy facilities and restoration of the environment (INUDECO 19): collection of documents of the IV International Conference, 24 - 26 April 2019, Slavutych. Chernihiv, ChNTU, 216.

21. Rozko, A., Fedorenko, Yu., Zadvernyuk, H. (2019). Zeolite as component binding materials for liquid radioactive waste conditioning. Exploratory and ecological geochemistry, 29 - 31.

22. Olkhovyk, Yu., Fedorenko, Yu., Rozko, A., Shkuropatenko, V., Saienko, S. (2019). Cementation of boroncontaining liquid radioactive waste at elevated temperature. Nuclear Energy and Environment, 1(13), 59 - 66.

23. GOST R52126-2003. Radioactive waste. Determination of chemical stability of cured high-level waste by the method of long-term leaching.

24. Rozko, A., Fedorenko, Yu., Pavlishin, G., Olkhovyk, Yu. (2020). The compressive strength of compounds obtained by cementing high-salt boron-containing LRW with geopolymer binders. Geochemistry of technogenesis, 4, 96-101. doi: 10.15407/geotech2020.32.096.

25. Zhygalov, Ya., Pshenychnyi, V. (2014). Determination of the attenuation factor of the equivalent dose of gamma radiation by the shell material of cylindrical containers for temporary storage of liquid radioactive waste. Nuclear and Radiation Safety, 1, $34-44$.

26. Krivenko, P., Cao, H., Petropavlovskii, O., Weng, L., Kovalchuk, O. (2016). Efficiency of Alkali Activated Hybrid Cements for Immobilization of Low-Level Radioactive AnionExchange Rezins. Eastern-European Journal of Enterprise Technologies, 5, 10(83), 38-42. doi: 10.15587/17294061.2016.59488.

27. Nuclear and Radiation Safety Rules during Transport of Radioactive Materials (PBPRM-2006) approved by SNRIU Order No. 132 of 30 August 2006 and registered in the Ministry of Justice of Ukraine under No. 1056/12930 on 18 September 2006.

28. Iwase, H., Niita, K., Nakamura, T. (2002). Development of general-purpose particle and heavy ion transport MonteCarlo code. Journal of Nuclear Science and Technology, 39, 1142 - 1151. doi: 10.1080/18811248.2002.9715305.

29. State Health and Safety Standards and Rules «Hygienic requirements for drinking water intended for human consumption» (DSanPiN 2.2.4-171-10) approved by Order of the Ministry of Health of Ukraine No. 40012.05.2010. Retrieved from: https://zakon.rada.gov.ua/laws/show/z0452-10\#Text.

30. Olkhovyk, Yu. (2015). Regarding the protective properties of the aeration zone of the Vektor site. Nuclear Energy and Environment, 2(6), 66 - 70.

\section{Regarding the Properties of Package for Disposal of Salt Melt from Ukrainian NPPs with WWER Reactors in Near-Surface Disposal Facilities}

\author{
Olkhovyk Yu. ${ }^{1}$, Fedorenko Yu. ${ }^{1}$, Rozko A. ${ }^{2}$, \\ Rudychev Y.,4
}
${ }^{1}$ State Institution «Institute of Enviromental Geochemistry of National Academy of Sciences of Ukraine», Kyiv, Ukraine
${ }^{2}$ M. P. Semenenko Institute of Geochemistry, Mineralogy and Ore Formation of the National Academy of Sciences of Ukraine, Kyiv, Ukraine ${ }^{3}$ Institute of High-Energy Physics and Nuclear Physics, National Science Center «Kharkiv Institute of Physics and Technology» of the National Academy of Sciences of Ukraine, Kharkiv, Ukraine
${ }^{4}$ V. N. Karazin Kharkiv National University, Kharkiv, Ukraine

The current situation with storage of salt melt generated since 1987 in NPP storage facilities was considered. It is noted that Zaporizhzhya NPP is close to the problem of shortage of free volume for temporary storage of containers with salt melt.

The properties of the hypothetical package acceptable for the disposal of salt melt without its processing in the event of a change in the classification of salt melt in the context of the entry into force in 2021 of the new classification of radioactive waste were considered in detail. It is noted that the main protective barrier during package disposal in a near-surface disposal facility will be a geocement matrix, which can be considered as a promising environment for the immobilization of the liquid salt concentrate or spent filter materials. The results of experiments on the resistance of slag-alkali compounds to leaching and exposure to radiation are presented. Calculated dose rate values on package surface are less than $2 \mathrm{mSv} / \mathrm{h}$. It is shown that despite a high content of nitrates in the package, even under simultaneous destruction of all containers, water layer distribution in the aquifer with nitrate ion concentration of more than $50 \mathrm{mg} / \mathrm{dm}^{3}$ will not exceed 100-150 meters from the outer boundary of the storage.

It is concluded that the use of an insulating geocement barrier is the main condition for forming the package for safe and environmentally friendly disposal of salt melt in near-surface disposal facilities.

Keywords: salt melt, immobilization, geocement matrix, container, near-surface disposal facility.

Отримано 08.12.2020 